på i amerikansk filosofi, som ligger så godt i forlængelse af Peirce, "nu måske er ved at vise sig at være udødelig [sic!] som filosofiens dominerende metodologi" (s.156). Hvis der nogensinde har været et eklant eksempel på filosofihistorie som fornuftens gang igennem historien, er det vist her. Ironisk nok er den grundlæggende motivation bag Misak’s egen Peirceanske position (og dermed også bag hendes fortælling om pragmatismens historie) faktisk et ønske om at kunne argumentere imod et magt-er-ret perspektiv, men hun synes helt blind for at hendes egen historie selv fremtræder som et relativt usofistikeret forsøg på at få den herskende form for pragmatisme til at fremstå som den rette. Dette vil uden tvivl medvirke til at en lang række filosoffer vil opleve hendes bog som en behagelig forsikring og påmindelse om at de er på rette vej. Men kampen om begrebet pragmatisme vil utvivlsomt også fortsætte, som en af mange arenaer for filosofisk strid, og det store spørgsmål er måske om det overhovedet er et begreb, som det er værd at kæmpe for.

Martin Ejsing Christensen

\title{
Haugelands Heidegger
}

Jobn Haugeland (redigeret af Joseph Rouse): Dasein Disclosed: John Haugeland's Heidegger, Harvard University Press, 2013, 336 sider, 49,95 USD.

John Haugeland (1943-2010) er herhjemme nok primært kendt for at være en betydelig stemme i kunstig intelligens forskningen op gennem 80'erne og 90'erne (Mind Design (1981); Artificial Intelligence: The Very Idea (1985); Mind Design II: Philosophy, Psychology, Artificial Intelligence. Second Edition (1997) ). Andre har måske stiftet bekendtskab med visse af hans analytisk-filosofiske artikler, hvoraf mange er samlet i bogen Having Thought, fra 1998. Af fremragende artikler heri kan nævnes, The intentionality all-stars, hvori Haugeland beskriver forskellige intentionalitets-teorier som de forskellige positioner i et spil baseball, og Represenational Genera, som Daniel Dennett i sin anmeldelse af bogen mener bør læses, hvad enten man er enig 
med Haugeland eller ej, ene og alene af den grund, at den er eksemplarisk i sin filosofiske opbygning. Ved siden af denne produktion har Haugeland desuden været nedsunket i Heideggers forfatterskab, centreret omkring Sein und Zeit, og cirka hvert 10. år udgivet en læsning af noget Heideggersk, der har været med til at sætte nye standarder. Her kan for eksempel nævnes, Heidegger On Being a Person, fra 1982, refereret til i Brandoms Making it Explicit i diskussionen af regularisme og regularitet. Nu er Haugelands artikler om Heidegger så samlet og udgivet i bogen Dasein Disclosed, inklusiv et manuskript han var i gang med om Heidegger da han tragisk døde af et hjertetilfælde ved en konference til ære for ham selv.

Haugeland havde en BA i fysik og var PhD i filosofi fra Berkeley (1976) under Hans Sluga. Han var desuden assistent for Hubert Dreyfuss på Berkeley, og var angiveligt en meget vigtig samtalepartner for Dreyfuss i dennes fortolkning af Heideggers SuZ (eller faktisk kun første sektion af første del) $\mathrm{i}$ bogen Being in the world, der nok har sat sit præg på den angloamerikanske forståelse af Heidegger. Haugeland underviste på University of Pittsburgh indtil 1999, fra 1986 som professor, og var kollega til blandt andet Robert Brandom, John McDowell og Jim Conant. Sammen med sidstnæunte redigerede han desuden en bog indeholdende artikler af og interviews med den sene Kuhn, der belyser dennes tænkning efter The Structure of Scientific Revolutions. Fra 1999 til sin død var han professor på University of Chicago, hvor konferencen til ære for ham selv blev afholdt, med prominente deltagere som John McDowell, Steven Crowell og Joseph Rouse. De to sidste hævder begge, i deres respektive mindeord til Haugeland, at det er dennes fortjeneste og eksempel der muliggjorde, i deres akademiske karrieres begyndelse i 80'erne, at bevæge sig i både fænomenologien og den analytiske filosofi, og samtidig blive taget seriøst. Det er samtidig en karakteristik man mærker i de fleste af Haugelands meget velskrevne artikler, nemlig at hvor det handler om Heidegger lurer analytiske problemstillinger $\mathrm{i}$ baggrunden og omvendt, når f.eks. Searle og Dennett tages under behandling, er det svært ikke at mærke en hermeneutisk ansporing også.

Rouse har redigeret denne posthume udgivelse og har samtidig forfattet en rigtig god indledning, samt suppleret med opklarende kommentarer de steder i de hidtil uudgivne manuskripter, hvor 
Haugeland ikke var helt færdig eller havde skrevet noter i margenen. Bogen er opdelt i 4 sektioner: sektion et indeholder to tidlige artikler om Heidegger, Heidegger on Being a Person (1982) og Dasein Disclosed (1989); sektion to indeholder det føromtalte ikke færdiggjorte Heidegger manuskript; sektion tre indeholder 3 senere artikler om Heidegger, Reading Brandom Reading Heidegger (2005), Letting Be (2007) og Truth and Finitude (2000), desuden har Rouse valgt at inkorporere henholdsvis en uudgiven artikel Death and Dasein (2007) og et foredrag Temporality (2002); den sidste sektion, fire, består af to artikler der ikke direkte omhandler Heidegger, men som Rouse har valgt at bringe som afslutning på bogen, fordi de viser hvordan Haugeland forstod Heideggerske temaer i en bredere forstand i relation til den samtidige filosofi. Disse to artikler hedder henholdsvis Social Cartesianism (2004) og Authentic Intentionality (2002).

Det her er så absolut en interessant bog. Både fordi den er et udtryk for en dygtig filosofs livslange beskæftigelse med Heidegger, og fordi Haugeland er så eminent en formidler som han er. Men også fordi den bidrager med en række af originale forståelser af Heidegger (om det så kun gælder i den angloamerikanske kontekst, skal jeg lade være usagt, der findes så meget litteratur om Heidegger at det er svært at overskue). Jeg vil kort nævne en tre stykker her: om tolkningen af Dasein, en terminologisk spidsfindighed og det nævnte manuskript ovenfor.

Hvordan skal vi forstå Dasein? Groft sagt, handler det om at styre imellem to mulige forståelser for Haugeland. På den ene side skal Dasein ikke forstås som et enkelt individ, ej heller i en aggregeret forstand, som en Dasein for hvert individ. På den anden side er Dasein heller ikke en social entitet, som et fælleskab. Den sidste forstålse var ellers Haugelands i den ovennævnte artikel Heidegger on being a person, hvor han formulerede tesen, at al konstitution er (social) institution. I stedet hævder (den senere) Haugeland, lig en af Heideggers karakteristikker af Dasein, at denne er "living a way of life that incorporates an understanding of being". I stedet for en social institution (af normer for, hvordan f.eks. ting forstås) betyder det, at living a way of life (der skal forstås pluralistisk, ways) konstitueres af den verden $\mathrm{i}$ hvilken Dasein befinder sig, men $\mathrm{i}$ en sådan forstand at eventuelle entiteter Dasein måtte støde på, indlemmes i Daseins way of life uden at de mister deres autoritet i forhold til, 
hvordan de så forstås. Samtidigt, er disse ways of life individualiseret - hvad Heidegger kalder jemeinigkeit - fordi de leves gennem personer der forstår sig selv gennem disse ways of life og er "kaldet" (efter Heideggers beskrivelse af skylden og samvittigheden) til at tage ansvar for forståeligheden af denne livsmodus (i bogen Having Thought optræder denne ansvarlighed som et af Haugelands kernebegreber, existential commitment, men uden den omfattende Heideggerske forståelsesramme, som vi så får her).

Rouse har desuden tilføjet en hel lille ordbog af Haugelands oversættelser af dele af den centrale Heideggerske terminologi, i kontrast til Macquarrie og Robinsons noget outdated oversættelse af SuZ. For eksempel, hvor Macquarrie og Robinson oversætter Heideggers Rede til discourse, oversætter Haugeland det til telling. Dermed kan han anslå forbindelser mellem at fortælle, at kunne skelne, telling apart, og vurdere om noget er korrekt, tell whether. I Haugelands oversættelse kommer Heideggers Rede som en artikulation af forståelighed til sin ret, fordi det dermed indbefatter andet end bare sproget.

Til sidst det der skulle have været kulminationen på Haugelands tolkning af SuZ, nemlig manuskriptet han ikke nåede at blive færdig med. Som en slags forord til dette manuskript (der også bærer navnet Dasein Disclosed) har Rouse valgt at trykke Haugelands ansøgning fra et modtaget Guggenheim Fellowship, der trækker de overordnede linjer op for den bog, manuskriptet skulle munde ud i. Og det er og var et ambitiøst foretagende, med tilhørende styrker og svagheder. Som bekendt skulle SuZ være i to dele, hver med tre sektioner, men kun de to første sektioner af første del udkom. Haugelands intention var, med dette manuskript, på den ene side, at give et bud på, hvordan hele første sektion kunne se ud, ved at bruge Heideggers forelæsninger fra lige efter udgivelsen af SuZ - og specielt Die Grundprobleme der Phänomenologie (GA 24), som Heidegger selv hævder aftegner den manglende tredje del fra SuZ (selve forelæsningen var, som SuZ, ikke færdiggjort). På den anden side var intentionen også at tolke denne første del af SuZ så analytisk mindede filosoffer, der ikke eller i meget begrænset omfang havde beskæftiget sig med Heidegger, kunne relatere til den, men uden at fortolkningen skulle munde ud i en slags Heidegger, nu som analytisk filosof. Kombineret var ambitionen, ifølge Hauge- 
land, dels at forsøge at ruske lidt op i Heiddeggerkredse, dels danne grobund for en afmontering af splittelsen mellem analytisk og kontinental filosofi og, sidst men ikke mindst, forsøge at fremme en mindre isoleret beskæftigelse med Heidegger.

Hvis vi tager de få svagheder først, så er der jo det at manuskriptet desværre ikke nåede at blive færdig, selvom Rouse, $\mathrm{i}$ indledningen, prøver at relatere det til sektion tre så det giver en tilnærmelsesvis fuldendelse og forståelse af, hvor Haugeland ville hen. For det andet er det, ikke udelukkende som følge af det første, noget ensidigt i sin forståelse af Heidegger, såfremt vi kigger på Heideggers forfatterskab som en helhed. Der er ingen diskussion af den komplekse sammenhæng mellem hvad, i Heideggers optik, der fortsættes fra SuZ projektet, og hvad der nødvendiggør en reorientering. Og det gælder specielt den sammenhæng, der er i forholdet mellem Dasein og spørgmålet om væren, hvilket er helt centralt for Haugeland, men indeholder en, måske flere, accent- forskydninger hos Heidegger efter SuZ. (næste generation af de amerikanske Heideggerfortolkere - f.eks. Mark Wrathall, Iain Thomson eller Taylor Carman - tager derimod dette op).

Men det er måske også dets styrke, for det skaber også en yderst original tolkning af betydningen af Heideggers projekt for nutidige filosofiske problemstillinger, f.eks. forholdet mellem biologiske og sociale forståelser af intentionalitet, den videnskabsteoretiske diskussion om realisme, sandhedsbegrebet og intentionalitetens iboende modalitet. Af hvilke, her til slut, kort skal nævnes den sidste, modalitetsbegrebet. Haugeland forstår den ontologiske differens modalt, dvs. forholdet mellem entiteter og deres væren udgør i vores forståelse en distinktion mellem, hvad der er muligt og umuligt for selvsamme entiteter. Den modale forståelse er desuden både normativ og aletisk. Dvs. at "lovmæssigheder", for nu at tage et eksempel (forstået bredt som både naturlige, logiske, moralske osv.), ikke kun beskriver hvordan tingene nødvendigvis er, de foreskriver også hvordan tingene bør forstås. Dvs. man tolererer ikke brud på naturlove, hvis man f.eks. er biolog, logiske modsætninger, hvis man er logiker, eller dårligt håndværk hvis man er tømrer. Men disse "lovmæsigheder" er kun partielle beskrivelser af modaliteten for det ontologiske område de hører til, fordi entiteternes mulighe- 
der/umuligheder er udtryk for et holistisk træk ved dette område og ikke en individuel egenskab. Det betyder så også, at vi i vores forståelse af entiteternes modalitet forpligter os på mere end der kan udtrykkes eksplicit gennem lovmæssigheder, fordi, som Rouse hævder $\mathrm{i}$ indledningen "Even in those scientific fields in which the explicit articulation of laws has been of central concern, there is arguably no example of an extensionally complete set of laws for a domain" (p. xv). Samtidig har forpligtelsen betydning ikke kun for de forskellige områder plus tilhørende entiteter vi er engageret i, men også for vores eget liv og muligheder. Så Dasein er, som living a way of life, udtryk for en modal forståelse af væren, der forsøger at lade forskellige muligheder, for tingene og sig selv, være til. Så, med Haugelands Heidegger har vi fået en ny forståelse af modalitet, en eksistential modalitet.

Med Having Thought og nu Dasein Disclosed er konturerne af en reflekteret, velartikuleret og sofistikeret filosofisk position lagt fremsom for fremtiden sandsynligvis vil blive en inspirationskilde for en række temaer på tværs af den analytiske og kontinentale filosofi, og måske rippe lidt op i meget af den eksegetiske Heideggerforskning.

Bo Allesoe Christensen

\section{Levende lærer af de døde - retsmedicinens udvikling i de vestlige samfund}

Katherine D. Watson:

Forensic Medicine in Western Society. A History, Routledge, 2011 , 214 sider, 32,95 USD.

Eftersom retsmedicinen omfatter medicinens anvendelse i retsvæsenets tjeneste, befinder den sig i et interessant krydsfelt mellem to af det moderne samfunds mest betydningsfulde vidensområder og institutioner. Samtidig danner det retsmedicinske videns- og praksisfelt et fascinerende sammenrendspunkt for en række af vor tids 